Scientific Review - Engineering and Environmental Sciences (2021), 30 (1), 98-105

Sci. Rev. Eng. Env. Sci. (2021), 30 (1)

Przegląd Naukowy - Inżynieria i Kształtowanie Środowiska (2021), 30 (1), 98-105

Prz. Nauk. Inż. Kszt. Środ. (2021), 30 (1)

http://iks.pn.sggw.pl

DOI 10.22630/PNIKS.2021.30.1.9

Zeyad K. ABDULLAD ${ }^{1}$, Shatha Y. Al-SAMARRAI ${ }^{2}$

${ }^{1}$ Iraqi Ministry of Oil, North Oil Refineries Company

${ }^{2}$ Tikrit University, College of Science

\title{
Modified solid ion-selective electrode for potentiometric determination of sulfide in oil refineries water
}

Key words: ion-selective electrode, silver sulfide, oil refineries, water

\section{Introduction}

A scientist, developed electrode membranes at the beginning of the twentieth century with the discovery of the glass electrode, which is one of the important tools in laboratories, as it response to hydrogen ions (Skoog, Holler $\&$ Nieman, 1998). Among the different analytical techniques (Mahajan, Kaur, Sharma \& Kumar, 2002) and as a result of the development of research, advances in this area began in the 1960s, when Rokosing and Pungor developed a new type of solid sensor (Cattral, 1997). The field of ion-selective electrodes has experienced rapid growth since the past two decades (Arida, Ahmed \& El-Saied, 2003), and chemical sensors are miniature analytical devices that can provide information about the presence of specific compounds or ions in complex samples (Wroblewski, 2009), which are dependent on the development of static electricity potential difference across a membrane. It separates two phases. When placed in a solution containing ions (Cattral, 1997), it is one of the most importantly fast and simple modern electrolysis techniques that require the current passing through them to be equal to zero (Othmer, 1981).

The use of ion-selective membrane electrodes is a good analytical technique. Due to its several advantages over conventional analysis methods for example they provide accurate, repeatable, fast, and often selective identification of different ions (Liu, Zhao, Chen \& Che, 2000). Sulfide is an anion that is widely present in both natural, wastewater, and industrial waters, and it is one of the most important factors to monitor in water due to its high toxicity to aquatic organisms. The sulfide toxicity is attributed to the release of hydrogen sulfide $\left(\mathrm{H}_{2} \mathrm{~S}\right)$ (Huang et al., 2010) and hydrogen sulfide $\left(\mathrm{H}_{2} \mathrm{~S}\right)$ is one of the most dangerous highly cor- 
rosive media (Lusk, Gupta, Boinapally $\&$ Cao, 2008). Because sulfide solutions can attack metals and concrete causing corrosion problems (Shao, Ying \& Ping, 2020). It is now known that corrosion can have some effects on the chemistry of the specific process, and the product of corrosion can affect the reaction and purity of the reaction products (Popoola, Grema, Latinwo, Gutti \& Balogun, 2013). Recent industrial disasters indicate that many industries have lost several billion dollars as a result of corrosion (Oyelami \& Asere, 2011).

The ion-selective sulfide electrode has been applied to monitor sulfide in industrial waters, and $\mathrm{Ag} / \mathrm{Ag}_{2} \mathrm{~S}$ electrode is the solid-state that uses this type of ion-selective electrode $\left(\mathrm{S}^{-2}\right)$ (Zaidan, 2007; Ding, Pan, Huang, Chen \& Ye, 2015). These electrodes contain in their crystal membranes only two crystalline compounds, they are the responsible materials for the electrochemical behavior of the membranes, and they are monocrystalline, where the membrane can be got by pressing or dissolving salt powder and then attaching it to the end of the electrode body made so it is not affected by air temperatures and is not subjected to cracking because of heat or rag and resists chemical changes such as the selective fluoride electrode (LaF3). The other such electrodes are the polycrystalline which can be prepared from $\mathrm{Ag}_{2} \mathrm{~S}, \mathrm{CuS}$, $\mathrm{CdS}, \mathrm{AgCl}, \mathrm{AgI}$, or $\mathrm{AgBr}$ powder selective for sulfide ions, chloride, iodide, or bromide respectively (Anfalt \& Jagner, 1969; Vesely et al., 1972). These films have been developed to prepare ion-sensitive selective membranes, where they are used to identifying many of the same ions as an internal solution for a con- ductor (Dulkiewicz, 1989; Bühlmann, Pretsch \& Bakker, 1998).

The aim of this study is to manufacture a selective electrode to determine the sulfur ions prepared from the reaction of sodium sulfide with silver nitrate to form silver sulfide by sedimentation method and apply it to measure sulfur ions in industrial waters in the production units of oil refineries of North Oil Refineries Company, Iraq, and compared with sensitivity and response of Sindie sulfur analyzer (model 7039 G3).

\section{Material and methods}

\section{Instrumentations}

The following instruments were used: $\mathrm{pH} / \mathrm{mV}$ meter (3310 Jenway); silver-silver chloride electrode as working electrode (Jenway); reference calomel electrode (Hanna); PVC tubing; balance (BL 210S Sartorius); magnetic stirrer with hotplate (LMS-1003 LabTech); drying oven (Memmert); test sieve (analysensieb) $(200 \mathrm{~mm}$, dia. $\times 50 \mathrm{~mm}$, ASTM E1175 micron) (D-42781 Haan); sulfur analyzer (7039 G3 Sindie).

\section{Reagents and solutions}

All reagents were of high purity grade supplied by Fluka, BDH, and MUMBAI. Sodium sulfide $0.1 \mathrm{M} \mathrm{Na} \mathrm{Na}_{2} \mathrm{~S}$ was used to prepare the standard solution, nitric acid $\mathrm{HNO}_{3}, \mathrm{NaOH}$. The sulfide anti-oxidant buffer SAOB containing $2 \mathrm{M}$ $\mathrm{NaOH}, 0.2 \mathrm{M}$ ascorbic acid, and $0.2 \mathrm{M}$ disodium EDTA (Dulkiewicz, 1989). Standard staggered ionic solutions were prepared at a concentration of $0.1 \mathrm{M}$ of $\mathrm{KBr}, \mathrm{BaCl}_{2}, \mathrm{SnCl}_{2} \cdot 2 \mathrm{H}_{2} \mathrm{O}, \mathrm{CuSO}_{4} \cdot 5 \mathrm{H}_{2} \mathrm{O}$, 
$\mathrm{Pb}\left(\mathrm{NO}_{3}\right)_{2}, \mathrm{CrCl}_{3}$ in a volume of $100 \mathrm{ml}$ distilled water.

\section{Preparation of $\mathrm{Ag}_{2} \mathrm{~S}$ electrodes}

The $\mathrm{Ag}_{2} \mathrm{~S}$ electrodes used in this study were fabricated by slow addition of $200 \mathrm{ml}$ of $0.5 \mathrm{ml}$ of silver nitrate solution using a burette, at a rate of 100 drops per minute to $100 \mathrm{ml}$ of $0.5 \mathrm{M}$ sodium sulfide solution with continuous stirring, and after completing the addition process, it was filtered. The resulting sediment was washed several times with distilled water, and then with diluted $0.1 \mathrm{M}$ nitric acid, the sediment was dried in an oven at $120^{\circ} \mathrm{C}$ for $3 \mathrm{~h}$. The sediment was collected, milled, and homogenized using ceramic mortar until it became a very fine powder and it was made using a $300 \mu \mathrm{m}$ sieve, the material was pressed in the form of hard disks using a medicinal pill making machine and it became a compact hard disk with a thickness of $0.7 \mathrm{~mm}$, a diameter of $11.9 \mathrm{~mm}$ and a weight of $0.8639 \mathrm{~g}$.

\section{Construction of ion-selective electrodes}

A PVC diameter was cut into $3-4 \mathrm{~cm}$ long pieces. An $\mathrm{Ag}_{2} \mathrm{~S}$ disk was placed in one end and the other end of the PVC tube was connected to an empty and open $\mathrm{Ag} / \mathrm{AgCl}$ (Fig. 1).

\section{Cell design and calculation of electrode potential}

The selective electrode potential can be calculated depending on the voltage of the membrane that separated different solutions containing the same concentrations of the metal since the response of these membranes depends on the ion

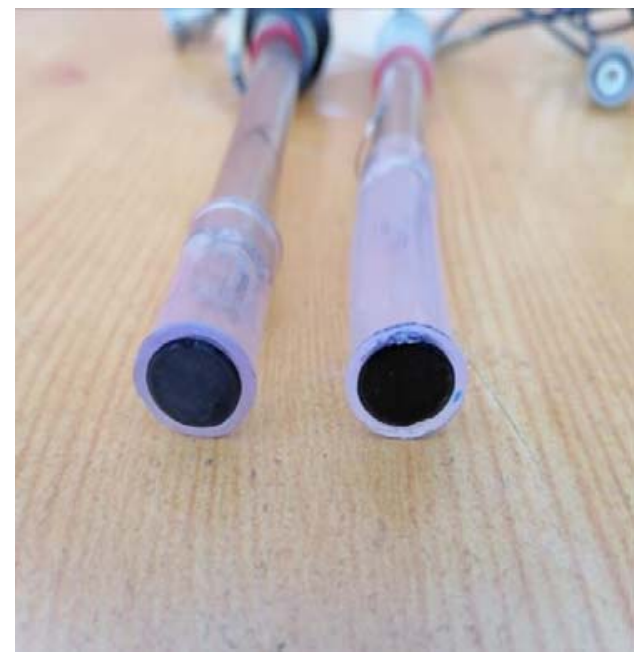

FIGURE 1. The installation of the manufactured electrode

exchanges present in them and has a selectivity of the desired ion. Without the other ions, depending on two main factors the size and charge of the ion, and given that the current passing through these electrodes is equal to zero, the cell used to measure the voltage of this type of electrode is shown in the following:

$\mathrm{Ag} / \mathrm{AgCl} \mid$ internal solution of $\mathrm{Na}_{2} \mathrm{~S}$ $\left(10^{-6} \mathrm{M}\right) \mid$ membrane $\left(\mathrm{Ag}_{2} \mathrm{~S}\right) \mid$ external solution of $\mathrm{Na}_{2} \mathrm{~S}(\mathrm{X} \mathrm{M}) \mid \mathrm{SCE}$

\section{Results and discussion}

In this study, the sedimentation method was used to prepare silver sulfide $\left(\mathrm{Ag}_{2} \mathrm{~S}\right)$, which is the material from which the membrane electrode is made, because this method works to accomplish chemical reactions in a fast, simple, and highly efficient way Energy and less time consuming and the properties as shown in Table 1 . 
TABLE 1. Properties of the prepared electrode

\begin{tabular}{|c|c|c|c|c|c|c|}
\hline $\begin{array}{c}\text { Lifetime/ } \\
\text { /month }\end{array}$ & $\begin{array}{c}\text { Response } \\
\text { time } \\
{[\mathrm{s}]}\end{array}$ & $\begin{array}{c}\text { Slope } \\
{\left[\mathrm{mv}^{\left.-\mathrm{decade}^{-1}\right]}\right.}\end{array}$ & $\begin{array}{c}\text { Detection } \\
\text { limit } \\
{[\mathrm{M}]}\end{array}$ & $\begin{array}{c}\text { Working } \\
\mathrm{pH} \text { range }\end{array}$ & $\begin{array}{c}\text { Linear } \\
\text { range } \\
{[\mathrm{M}]}\end{array}$ & $\begin{array}{c}\text { Working } \\
\mathrm{pH} \text { range }\end{array}$ \\
\hline 4 & $5-17$ & 28.229 & $2.28 \cdot 10^{-7}$ & $6.0-12.0$ & $10^{-1}-10^{-6}$ & $\mathrm{~S}^{-2}$ \\
\hline
\end{tabular}

\section{Effect of temperature}

The best range of temperature without significantly affecting the electrode voltage was $25-35^{\circ} \mathrm{C}$, and there is an increase in the voltage difference values at higher temperatures of $35^{\circ} \mathrm{C}$, which may occur because of the increase in the movement of $\mathrm{S}^{-2}$ in and out of the electrode and the increase in the surface area of the fabricated electrode membrane as the increase in the movement of the solution particles is directly proportional to the increase in the surface area directly with the temperature (Fig. 2).

\section{Response time}

Figure 3 shows the response time of the electrode, it could be noticed that the response time within a range of concentrations between $10^{-2}$ and $10^{-6} \mathrm{M}$ was be- tween 5 and $17 \mathrm{~s}$, and it is noticed that the response time is inversely proportional to the concentration of ions in the external solution. The concentration of ions increases in the external test solution, the response time decreases due to the easy access of the ions to the outer membrane of the electrode, and vice versa, as the concentration of ions decreases, the number of ions in the external solution will decrease, so it takes longer to reach a state of equilibrium in the electrode voltage.

\section{Calibration curve}

The standard calibration curve can be measured by preparing a series of solutions in question at concentrations ranging from $0.1 \cdot 10^{-1}$ to $0.1 \cdot 10^{-6} \mathrm{M}$, then measuring the voltage by the prepared

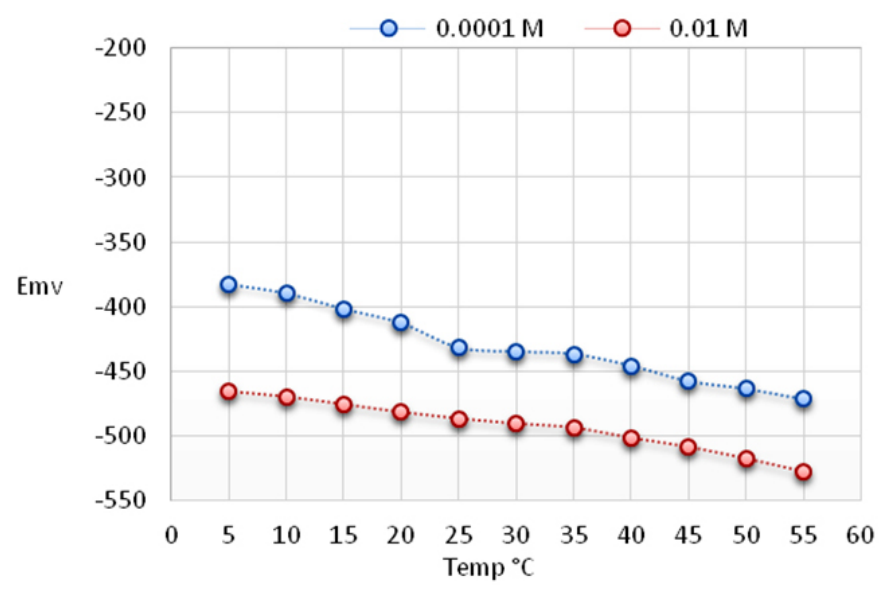

FIGURE 2. Effect of temperature on electrode response 


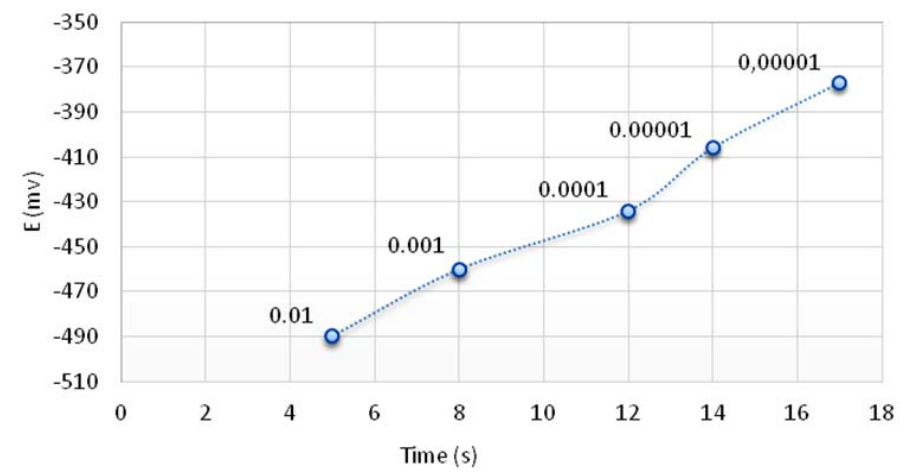

FIGURE 3. The response time of the electrode

selective electrode and drawing the relationship between the electrode voltage versus $-\log \left[\mathrm{S}^{-2}\right]$, while observing the movement of the model to affect the state of equilibrium. Figure 4 shows the effect of the concentration of the internal filling solution on the electrode response per decade, which was close to the theoretical value $29.58 \mathrm{mv}$ per decade, to be the concentration, and the electrode calibration curve the linear response of the opposites ranged between $1.00 \cdot 10^{-6}$ and $1.00 \cdot 10^{-1} \mathrm{M}$ and the minimum Nernst response $2.28 \cdot 10^{-7}$.

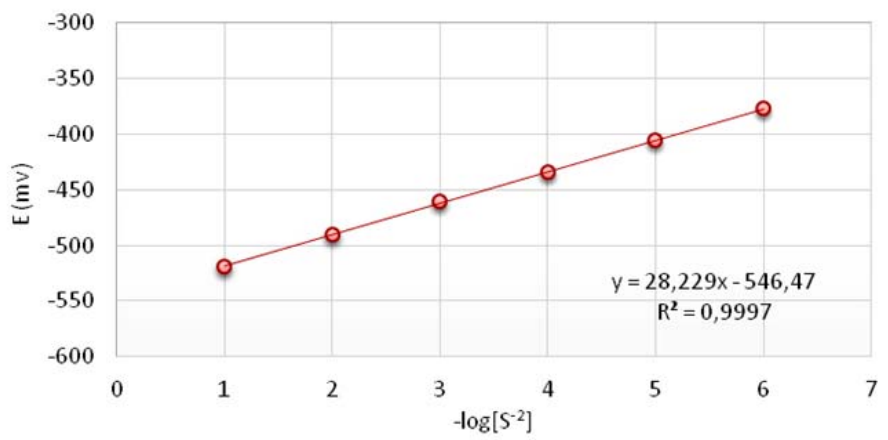

FIGURE 4. Standard curve of an electrode

after fixing the other conditions, temperature and $\mathrm{pH}$ where it was observed that the concentrations less than $10^{-6} \mathrm{M}$ did not show any linear response and it was neglected in the subsequent experiments, and the internal filling solution was at concentration $10^{-6} \mathrm{M}$ is the best internal packing solution because the best Nernst slope response $28.229 \mathrm{mv}$

\section{Selectivity}

Selectivity is the most important characteristic that determines the nature of an electrode and the extent to which it can be used successfully. The values of the selectivity coefficient (Table 2) were determined against the number of interfering ions, using the mixed solution method, the selectivity coefficient can be 
TABLE 2. Selectivity values of $K_{A, B}^{P o t}$

\begin{tabular}{|c|c|c|}
\hline \multicolumn{2}{|c|}{$\begin{array}{c}\text { Concentrations of } \mathrm{Na}_{2} \mathrm{~S} \\
{[\mathrm{M}]}\end{array}$} & $\begin{array}{c}\text { Interfering species } \\
10^{-2} \mathrm{M}\end{array}$ \\
\cline { 1 - 2 }$K_{A, B}^{\text {Pot }}$ values & \\
\hline $10^{-4}$ & $10^{-2}$ & \\
\cline { 1 - 2 } 0.0470 & 0.0390 & $\mathrm{~K}^{+1}$ \\
\hline 0.0046 & 0.0320 & $\mathrm{Cu}^{+2}$ \\
\hline 0.0081 & 0.0300 & $\mathrm{Zn}^{+2}$ \\
\hline 0.0069 & 0.0490 & $\mathrm{~Pb}^{+2}$ \\
\hline 0.0053 & 0.0082 & $\mathrm{Cr}^{+3}$ \\
\hline 0.0048 & 0.0270 & $\mathrm{Cl}^{-1}$ \\
\hline 0.0064 & 0.0880 & $\mathrm{Br}^{-1}$ \\
\hline 0.0710 & 0.0540 & $\mathrm{SO}_{4}^{-2}$ \\
\hline
\end{tabular}

expressed by the relative error and concentration of the ion to be analyzed to the interfering ion by Eq. (1):

$K_{A, B}^{P o t}=\frac{C_{A \min } \cdot P}{C_{B \text { max }} \cdot 100}$

$K_{A, B}^{P o t}$ - selectivity coefficient of the ion selection electrode (A) in the presence of the interfering ion $(\mathrm{B})$,
$C_{A_{\text {min }}}$ - the lowest expected concentration of the ion to be analyzed,

$C_{B_{\max }}$ - maximum expected concentration of the interfering ion,

$P$ - permissible relative error when analyzing the ion (A) due to ion interference (B).

\section{Accuracy and precision}

Table 3 shows the accuracy and agreement of the results of the standard curve of the electrode, noting that the extent of convergence between the real value and the laboratory values of the concentrations: $10^{-2}, 10^{-4}, 10^{-6} \mathrm{M}$, and that the percentage recoverable values in

TABLE 3. Accuracy and compatibility of the results of the standard curve of the electrode

\begin{tabular}{|c|c|c|c|c|}
\hline \%REC & \%RE & \%RSD & $\begin{array}{c}\text { Concen- } \\
\text { tration } \\
\text { thoughtful } \\
{[\mathrm{M}]}\end{array}$ & $\begin{array}{c}\text { Elec- } \\
\text { trode }\end{array}$ \\
\hline 99.9 & -0.1 & 0.5772 & $10^{-2}$ & \multirow{2}{*}{$\mathrm{S}^{-2}$} \\
\hline 103.7 & 3.7 & 0.7430 & $10^{-4}$ & \\
\hline 98.0 & 2.0 & 0.6352 & $10^{-6}$ & \multirow{2}{*}{-} \\
\hline
\end{tabular}

TABLE 4. Comparison method between the electrode and sulfur analyzer

\begin{tabular}{|c|c|c|c|}
\hline \multirow{2}{*}{$\%$ RE } & \multicolumn{2}{|c|}{ Concentration of $\mathrm{S}^{-2}\left[\mathrm{~mol} \cdot 1^{-1}\right]$} & \multirow{2}{*}{ Sample } \\
\cline { 2 - 3 } & $\mathrm{Ag}_{2} \mathrm{~S}$ electrode & sulfur analyzer & $\mathrm{S} 1$ \\
\hline 3.92 & $2.69 \cdot 10^{-2}$ & $2.8 \cdot 10^{-2}$ & $\mathrm{~S} 2$ \\
\hline 3.44 & $3.00 \cdot 10^{-2}$ & $2.9 \cdot 10^{-2}$ & $\mathrm{~S} 3$ \\
\hline-5.66 & $2.83 \cdot 10^{-3}$ & $3.0 \cdot 10^{-3}$ & $\mathrm{~S} 4$ \\
\hline 0.50 & $1.47 \cdot 10^{-2}$ & $1.4 \cdot 10^{-2}$ & $\mathrm{~S} 5$ \\
\hline-3.25 & $3.87 \cdot 10^{-4}$ & $4.0 \cdot 10^{-4}$ & $\mathrm{~S} 6$ \\
\hline-5.68 & $8.96 \cdot 10^{-4}$ & $9.5 \cdot 10^{-4}$ & $\mathrm{~S} 7$ \\
\hline-3.88 & $3.46 \cdot 10^{-4}$ & $3.6 \cdot 10^{-4}$ & $\mathrm{~S} 8$ \\
\hline 4.25 & $8.32 \cdot 10^{-4}$ & $8.0 \cdot 10^{-4}$ & $\mathrm{~S} 9$ \\
\hline 6.15 & $1.38 \cdot 10^{-3}$ & $1.3 \cdot 10^{-3}$ & $\mathrm{~S} 10$ \\
\hline 5.38 & $2.74 \cdot 10^{-4}$ & $2.6 \cdot 10^{-4}$ & \multicolumn{2}{c}{} \\
\hline
\end{tabular}


the range of $98-103.7 \%$ for the concentrations chosen from the standard curve, and the highest value of the relative standard deviation $(0.7430 \%)$. These results indicate high precision and electrode compatibility.

\section{Applications}

The method of comparison with the sulfur ion analyzer and the electrode that was the results was very close and the relative error was very small between the two methods, and this gives evidence of good selectivity and high sensitivity of the electrode as shown in Table 4.

\section{Conclusion}

The $\mathrm{Ag} / \mathrm{Ag}_{2} \mathrm{~S}$ electrode proved to be a suitable tool for measuring the concentrations of sulfur ions in solutions as well as in industrial water that used in the petroleum industries. It is characterized by ease of manufacturing and use, and it has a fast response time, long life, good selectivity, and high sensitivity.

\section{References}

Anfalt, T. \& Jagner, D. (1969). Effect of acetate buffer on the potentiometric titration of fluoride with lanthanum using a lanthanum fluoride membrane electrode. Analitica Chimica Acta, 47(3), 483-494.

Arida, H.A., Ahmed, M.A. \& El-Saied, A.M. (2003). A novel coated graphite rod Th(IV) ion selective electrode based on thorium oxinate complex and its application. Sensors, 3(10), 424-437.

Bühlmann, P., Pretsch, E. \& Bakker, E. (1998). Carrier-based ion-selective electrodes and bulk optodes. 2. Ionophores for potentiometric and optical sensors. Chemical Reviews, 98(4), 1593-1688.
Cattral, R.W. (1997). Chemical Sensors. Oxford: Oxford University Press.

Ding, Q., Pan, Y.W., Huang, Y. F., Chen, C.T.A. \& Ye, Y. (2015). The optimization of Ag/Ag2S electrode using carrier electroplating of nano silver particles and its preliminary application to offshore Kueishan Tao, Taiwan. Continental Shelf Research, 111, 262-267.

Dulkiewicz, R. (1989). An alternative approach to workplace air monitoring. Analyst, 114, 21-25.

Huang, D., Xu, B., Tang, J., Luo, J., Chen, L., Yang, L., Yang, Z. \& Bi, S. (2010). Indirect determination of sulfide ions in water samples at trace level by anodic stripping voltammetry using mercury film electrode. Analytical Methods, 2(2), 154-158.

Liu, Y., Zhao, B.T., Chen, L.X., \& He, X.W. (2000). Liquid membrane transport and silver selective electrode based on novel bis(3-pyridinecarboxylate) calix[4]arene as ionophore. Microchemical Journal, 65(1), 75-79.

Lusk, D., Gupta, M., Boinapally, K. \& Cao, Y. (2008). Armoured against corrosion. Hydrocarbon Engineering, 13(11), 115-118.

Mahajan, R.K., Kaur, I., Sharma, V. \& Kumar, M. (2002). Sensor for silver (I) ion based on Schiff-base-p-tertbutylcalix [4] arene. Sensors, 2(10), 417-423.

Othmer, K. (eds.) (1981). Encyclopedia of chemical technology. Hoboken, NJ: John Wiley \& Sons

Oyelami, B.O. \& Asere A.A. (2011). Mathematical modeling: an application to corrosion in a petroleum industry. In NMC Proceedings Workshop on Environment (pp. 48-66). Abuja, Nigeria: National Mathematical Centre.

Popoola, L.T., Grema, A.S., Latinwo, G.K., Gutti, B. \& Balogun, A.S. (2013). Corrosion problems during oil and gas production and its mitigation. International Journal of Industrial Chemistry, 4(1), 1-15.

Shao, Y., Ying, Y. \& Ping, J. (2020). Recent advances in solid-contact ion-selective electrodes: functional materials, transduction mechanisms, and development trends. Chemical Society Review, 49(13), 4405-4465.

Skoog, D.A., Holler, F.J. \& Nieman, T.A. (1998). Principles of instrumental analysis. Philadelphia: Saunders College Publishing.

Vesely, J., Jensen, O.J. \& Nicolaisen, B. (1972). Ion-selective electrodes based on silver sulphide. Analitica Chimica Acta, 62(1), 1-12. 
Wroblewski, W. (2009). Ion-selective electrodes. Warsaw: Chemical Sensors Research Group. Zaidan, T.A. (2007). Evaluation the precision of "doctore test" for mercaptans detection in petroleum products by sulphide ion-selective electrode. Journal of University of Anbar for Pure Science, 1(3), 41-44.

\section{Summary}

Modified solid ion-selective electrode for potentiometric determination of sulfide in oil refineries water. A selective electrode was manufactured to determine the sulfur ions by sedimentation method in industrial waters in oil refineries of North Refineries Company, Baiji, Iraq. The linear response on a wide range of concentration (from
$1.0 \cdot 10^{-1}$ to $\left.1.0 \cdot 10^{-6} \mathrm{M}\right) \mathrm{Na}_{2} \mathrm{~S}$ with a Nernst response of $28.229 \mathrm{mv}$ per decade, theoretical value for slope of $29.58 \mathrm{mv}$ per decade, correlation factor of 0.9998 , detection limit of $2.287 \cdot 10^{-7}$ at $25-35^{\circ} \mathrm{C}$, pH $6.0-12.0$, and the best concentration of the filling solution of $10^{-6} \mathrm{M}$ with a fast response time (5-13 s). The direct method were \%RSD for 0.5772 $-0.7430, \% \mathrm{RE}$ for $-0.1,3.7$ and $\%$ REC for 99.9, 103.7 .

\section{Authors' address:}

Shatha Y. Al-Samarrai - corresponding author (https://orcid.org/0000-0002-0389-1991)

Tikrit University

College of Science

Salahddin, Tikrit

Iraq

e-mail: dr.shatha81@tu.edu.iq 